\title{
To Domesticate or to Foreignize: An Approach to Translating Fables and Fairy Tales
}

\author{
Ala'a Jasim Obaid MA. Candidate \\ E-mail: ajalkinany@gmail.com \\ Asst. Professor Baydaa Ali Al-Obaydi (Ph.D) \\ E-mail: dr.baydaa99@uomustansiriyah.edu.iq \\ Al-Mustansiriya University, College of Arts, Department of Translation, \\ Baghdad, Iraq.
}

( Received on 25/2/2014 - Accepted on 30/3/2014 - Published on 2/1/2022 )

DOI: https://doi.org/10.36586/jcl.2.2022.0.45.0026

(c) (i)

This work is licensed under a Creative Commons Attribution 4.0 International License.

\section{Abstract}

The present study deals with the strategies used in the Arabic translations of the most popular genres of children's literature; namely fairy tales and fables as an attempt to identify the best methods and strategies to be adopted in translating these genres to fulfill the ultimate purpose of enriching the children's knowledge in addition to attracting their interest and arousing the joy sought for in every piece of literature. The study sets off from three dominating trends: the first calls for the adoption of domestication strategy of translation as the most appropriate and effective strategy in translation for children. In the same line, the second opposes using the foreignization strategy, while the third trend advocates for the joint employment of various strategies to fulfill certain requirements and needs that would be called upon within the context such as didactic purposes. 
Throughout the process of examining and verifying the theses of these trends, samples of translations of the genres are chosen based on the most popular and well known fairy tales and fables either circulated in written form or televised as movies or cartoons; namely Hans Christian Andersen's Fairy Tales and Aesop's Fables. These samples are subjected to translation quality assessment to come out with a quality statement to highlight their merits and demerits. The receptors' (children) impact is also sought via conducting a field study that has been designed for children of two age groups defined by specialized scholars as intended receptors of the genre.

Keywords: Children literature, domestication, foreignization, fairy tales.

\section{Introduction}

Translating for children, despite the fact that it is of assumed low status within translation studies, has certainly a great impact on the progress of the field of children's literature. Thus, its importance is undeniable on the flourishing of this genre.

\section{"[...] translations greatly improved the status of children's} literature and encouraged new initiatives, since by confronting authors with the best from elsewhere, they stimulated the production of literature in the national language. Translation was and remains a means of sharing creativity, new ideas, and literary models." (Ghesquiere in Klingberg, 2008 : 25)

Translating specifically for children and the adopted strategies for fulfilling this task are always confused for being mostly shared with those used for translating for adults. The bottom line is that though common strategies are embraced for both genres of receivers, attention should be paid to unique characteristics in each field as a part of the whole polysystem, as can be recognized in Even-Zohar's description of the literary polysystem, “...there is no awareness of the possible existence of translated literature as a particular literary system. The prevailing concept is rather that of "translation" or just "translated works" treated on an individual basis" (Even-Zohar, 2000: 193). 
Klingberg (2008:12-16) opines that the aims of the strategies used for translating for children should concentrate mainly on the intellectuality aspects such as attempting to enrich the readers' knowledge and to optimize their understanding of foreign cultures. He advocates for adopting translation strategies that encompass preservation of the spirit of the original. These strategies, according to him (ibid), should be preferred over any other strategies in order to bring the children closer to the culture and surroundings where the books originated from. What stands as an obstacle to this aim, is the translator's interventions in the STs via several methods of translation such as "cultural context adaptations", "purifications", "modernizations", "abridgements" and the "serious mistranslations" that occur within the translation process .

Translation is an intercultural process as Nord (2006:62) holds that "translating means comparing cultures". Baker (2009:221) sees that a foreignizing approach is "highly desirable to restrain the ethnocentric violence. Nida (1964: 130) declares that it is more important to be acquainted with more cultures rather than more languages for the translation to be successful since the language is only meaningful in its natural cultural background.

This is also applicable for the translation of children's literature. Zhang (2011:253 ) heralds that there are two strategies in translating the cultural factors in children's literature: Foreignization and Domestication. Foreignization subsumes the process of preserving the distinctive foreign elements of the ST in order to introduce the reader to concepts beyond those of his own culture and to increase his knowledge of the SL and source culture. Domestication, on the other hand, seeks to remove any exotic feature of the ST in the ST as an attempt to make it easier for the children readers to understand the foreign elements in expressions or structures familiar to the ST receptors. One method of fulfilling this end is to adopt literal translation strategy with addition of annotation (ibid: 254). The addition of the annotation gives the children readers more cultural information to ensure their better understanding of the foreign literature presented to them. Yet, it is noticed that only one version of the material chosen for this study (the one adopting literal 
translation strategy) supplies such annotation which are left unexplained in the other two versions (those adopting domesticated and foreignized strategies).

According to Shavit (1986: 112), translation for children is governed by the following two principles: "adjusting the ST in order to make it appropriate or useful for the child", and "adjusting the plot, characterization and language to the child's ability to read and comprehend". All these adjustments should abide by the society's norms i.e., what is good for the child and what the child can read and understand. These two principles might not always come in accordance with each other since sometimes they can even be contradictory. The most problematic issue in the adjustment of children's literature is the issue of the taboos. Taboos in children's literature are simply the topics that should not be introduced to the children since they violate the norms of the society they live in. Oittinen (2000: 86-87) considers the issue of taboo to be a critical issue that arouses problems and calls for certain strategies that should be followed in its translation.

There are various possible strategies to deal with taboos. Deletion of the taboos is the simplest method that is often used to avoid undesirable topics. Shavit (1986: 123,145) opines that it is almost a rule that translators delete unwanted words or scenes whenever it does not damage the basic plot or characterization. Manifestation of omission can be noticed repeatedly, especially in the domesticated translation involved in this study. The translator chooses to omit any word related to what he considers forbidden such as death, nudity, mouth kissing and slavery, for instance the words or clauses: "became earth" and "sung himself to death" which implies death, "quite naked", "kiss her fresh mouth" and "black slaves" are either wholly or partially omitted to evade unwanted concepts.

However, there are some instances where it is not possible to delete unwanted scenes or elements if they represent vital plot progression indications. Such elements are often altered into an acceptable format suitable for the audience (ibid). This method can be found in translations 
of many of Hans Christian Andersen's Fairy Tales as in She Was Good for Nothing where "ale" is transferred to "bread" or "sweet drink" in the Arabic translation and also in The Story of a Mother where "death" is rendered as the "angel of death" because such concepts ( alcohol and personification of abstract entities) are not very welcome to be explicated in the Arab world.

\section{Procedure}

The procedure of the study consists of two major orientations: the first is to present a translation quality assessment based on an adapted eclectic model that is derived from approaches that represent each of the functional (Nord, 1991,1997), post-modernist (Venuti, 1989) and the linguistically oriented approach (Hervey and Higgins, 1992) and House's assessment model (House, 1997), that provides the means for the analysis and comparison of an original text and its translation on three different levels: Language/Text, Register (Field, Mode and Tenor) and Genre.

Adherents of the functionalistic approach (Vermeer 1978/1996; Reiss and Vermeer 1984; Holz-Mänttäri 1984; Hönig and Kussmaul 1982) claim that it is the "skopos" or purpose of a translation that is of overriding importance in judging a translation's quality. The basic yardstick in evaluating a translation is how the target culture norms are heeded or flouted by a translation. It is the translator or more frequently the translation brief he is given by the person(s) commissioning the translation that decides on the function the translation is to fulfill in its new environment.

According to Nord, it does not matter which text-linguistic model is used in analysis as long as it includes "a pragmatic analysis of the communicative situations involved and that the same model be used for both the ST and the translation brief, thus making the results comparable" (Nord 2006: 62).

Nord does not assume much importance for the kind of text-linguistic model is used in analysis provided that it includes "a pragmatic analysis of the communicative situations involved and that the same model be 
used for both the ST and the translation brief, thus making the results comparable" (Nord 2006: 62).

Munday (2001:83) summarizes the following intra-textual factors listed by Nord as one possible model for ST analysis:

"Subject matter; content: including connotations and cohesion; presuppositions: real-world factors of the communicative situation presumed to be known to the participants; composition: including microstructure and macrostructure; non-verbal elements: illustrations, italics, etc.; lexic: including dialect, register and specific terminology; sentence structure; suprasegmental features: including stress, rhythm and "stylistic punctuation." (ibid)

Nord based her communicative model on Bühler's organon model (1934) in which Bühler proposes three basic functions of language: referential, expressive and appellative. Yet, she added another function, a fourth function, which she assumed to "be lacking in Bühler's model but is included in Roman Jakobson's model of language functions (1960): the phatic function"(Nord, $2006: 4$ ).

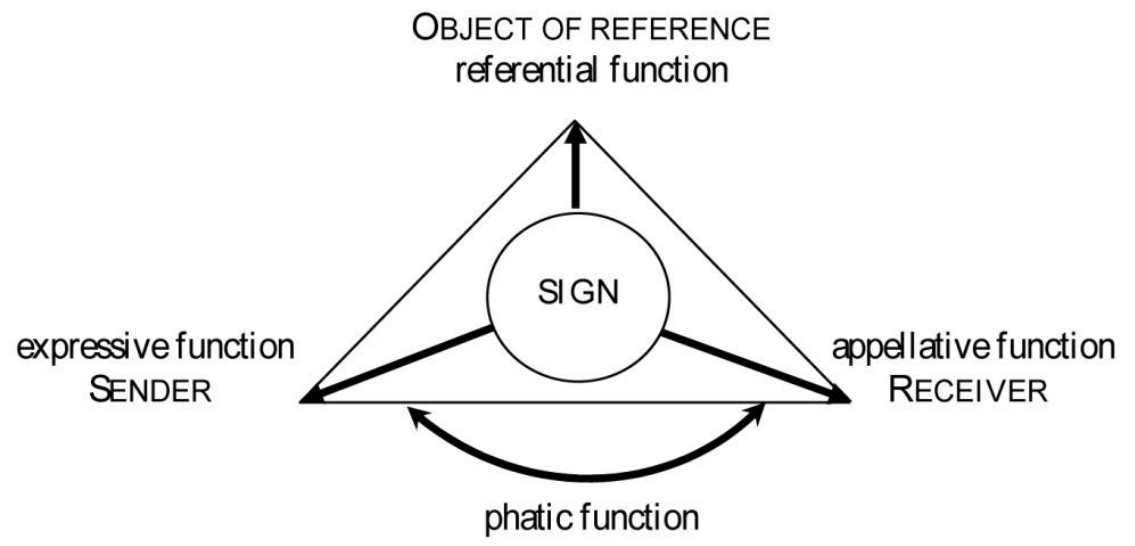

Figure (1) Functions of Language

(Nord, 1997: 135) 
Linguistic textual approaches is concerned with the relationship between the ST (and its features) and the way it is comprehended by the TL audience. This process, usually defined as "language in use", has become an indispensible part of language studies. The only difference, these approaches claim, is their capacity to come up with detailed techniques and procedures and hence, attaining more accurate analysis and evaluation.

Reiss and House are prominent names that influentially enriched the progress of linguistic textual approaches. Reiss (1971: 17) has introduced the notion of text type of the ST as the most important invariant in translation since it governs whatever decision the translator may make.. She sets of from Bühler's three functions of language: content-oriented texts, e.g., news, scientific, technical texts, form-oriented texts, such as poems and literary journal, and conative texts, e.g., advertisements and texts of persuasive bent such as religious brochures" differentiates three distinct text types (ibid).

While House's approach sets off from the notion that equivalence always underlies relative understanding that is reveals none of the its original identity features. Catford $(1965: 21)$ seconds this view by stating that “ the central problem of translation practice is that of finding TL equivalents. A central task of translation theory is, therefore, that of defining the nature and conditions of translation equivalence". House adopts the five 'frames of reference' introduced by Koller's (1992) in order to determine the type of equivalence: denotative, connotative, text normative, pragmatic, and formal-aesthetic equivalence"(Munday, 2001: 47). Her attitude towards the notion of equivalence the criticism it received can be seen as denouncing

"The attack against the concept of "equivalence" in the field of translation studies has a slightly dated touch. Formal definitions of equivalence have further been revealed as deficient in that they cannot explain appropriate use in communication. This is why functional, communicative or pragmatic equivalence have been accredited concepts in contrastive linguistics for a very long time, focusing as they do on 
language use rather than structure. It is these types of equivalence which have become particularly relevant for translation" (House, 1997: 26).

The ultimate revised model of House appears to be comprising four levels: function of the individual text, genre, register and language/text" (ibid:107), where the register analysis categories are subsumed under the Hallidayan concepts of field, tenor and mode (ibid:108). The analytical scheme for introduced by House for comparing original and translation texts can be illustrated in table (1) below:

To assert that translation evaluation involves elements beyond mere The analytic model $\mathrm{j}$

\section{INDIVIDUAL TEXTUAL FUNCTION}

\begin{tabular}{|c|c|c|}
\hline REG & TER & GENRE \\
\hline FIELD & ENOR & MODE \\
\hline Subject matter & $\begin{array}{l}\text { participant relationship } \\
\text { and social action }\end{array}$ & medium \\
\hline & author's provenance & simple/complex \\
\hline & and stance & \\
\hline & participation & \\
\hline & $\begin{array}{l}\text { social role relationship } \\
\text { social attitude }\end{array}$ & simple/complex \\
\hline
\end{tabular}

\section{LANGUAGE/TEXT}

Table (1) A Scheme for Analysing and Xomparing Original and Translation Texts (House, 1997: 108)

linguistic factors, House opines that: "The choice of an overt or covert translation depends not just on the translator himself, or on the text or the translator's personal interpretation of the text, but also, and to a 
considerable extent, on the reasons for the translation, on the implied readers, on publishing and marketing policies" (ibid:119).

The distinction between an "Overt Translation" and a "Covert Translation" goes back at least to Friedrich Schleiermacher's famous distinction between "verfremdende" (alienation) and "einbürgernde" ( integration ) Übersetzungen, which has had many imitators using different terms ( Munday, 2009:183).

The concepts of Schleiermacher gives a clear insight to the ethnocentric attitude of Venuti whose divisions of translation i.e., domestication resembles Schleiermacher's idea of bringing the author to the reader ( and hence adopting a kind of covert translation ) and foreignization which resounds Schleiermacher's view of sending the reader to the author ( and acting as overt translator ).

Based on the two norms governing translation for children , many translation strategies seem to be revolving around dichotomies such as literal vs. free, semantic vs. communicative, formal vs. functional and domestication vs. foreignization. The last pair becomes the center of much debate within Translation Studies and undergoes much debate since it reveals the concept of power and cultural effect in translated texts.

According to Schleiermacher (in Venuti, 1995: 19), "either the translator leaves the author in peace, as much as possible, and moves the reader towards him; or he leaves the reader in peace, as much as possible, and moves the author towards him". The act of "leaving the author in peace" may be equated to foreignizing the text 'as much as possible' and the act of "leaving the reader in peace" may be equated to domesticating it.

Coinciding with Schleiermacher's notion, Venuti (ibid) proposes two methods that are adequate for dealing with cultural elements: Domestication or Forignization. He holds a denouncing attitude towards the translation strategy (commonly adopted in the UK and the United States) where the translation is considered acceptable only if it is reads as fluently as the ST due to the translator's domestication of every peculiar 
stylistic or linguistic features. Therefore, the resulted translation sounds transparent and the translator invisible giving assuming giving the impression that it is not a translation but a an originally written text in the same language. (ibid:4-42)

Venuti asserts that translation practice is cultural communication, but what matters is the way of recasting the culture and making its features close or different than those of the original. This process is referred to as domestication, which involves recasting the foreign elements in the text into more familiar elements within the recognition of the target readers. This is expressed by Venuti as follows: “...foreign text is rewritten in domestic dialects and discourses, registers and styles, which results in the production of textual effects that signify only in the history of the domestic language and culture" (Venuti, 2000:209).

Therefore, the domestication process has a limited and redirected communicative aim of translation since it excludes the foreign elements of the target culture. Whereas, the translation aim is to foster communication even if containing exotic elements rather than domesticating those elements.

This can be manifested in the foreignized strategy adopting translator's rendering of "camel-driver” into "حادي الابل" ("hadi 'a'ebil” in Arabic) rather than simply "camel-man" ("aljammãl" in Arabic) used by the translator who adopts the domestication strategy.

Hervey and Higgins' model of translation includes a schema of five filters or categories "through which texts can be passed in a systematic attempt to determine their translation-worthy properties" (Hervey and Higgins, 2002: 224). These categories are the genre, cultural, formal, semantic, and varietal filters. Analysis on the genre level includes identifying the type of communication (oral or written), medium of communication, text type and ST subject.

At a closer look, several resemblances can be spotted in both Hervey and Higgins' filters and Nord's factors. These points of intersection are illustrated in the following: 
1. The analysis taken place in the genre filter that is concerned with type and medium of communication subsumes Nord's factors of subject matter and composition. Though Hervey and Higgins' model gives an account of non-verbal elements yet, they are not made explicit.

2. The cultural filter which examines all features in the ST that are exclusive to the source culture or SL subsumes the factor of presuppositions in Nord's model.

3. The semantic filter, which analyzes textual features related to literal and connotative meanings subsumes the factor of content in Nord's model,

4. The formal filter that examines features of the inter-textual, discourse, sentential, grammatical, prosodic and phonic/graphic levels of the text subsumes factors of composition, sentence structure and suprasegmental features.

5. The varietal filter, that investigates the textual features related to dialect, sociolect, social register and tonal register that may exist in the ST, subsumes Nord's lexic factor.

Hervey and Higgins (2002:25) opine that translation is vulnerable to some loss in meaning therefore, translation loss is inevitable. They stress that the translator's job is to diminish this loss to the most possible extent rather than seeking perfect or ideal translation. This goal cannot be attained without determining the most important elements in the ST in order to decide whether they are crucial to be preserved or discarded (ibid).

The change that occurs to translation does not include only loss but also addition of textual features to the TT. Hervey and Higgins call this "gain in translation" which includes adding more elements to the TT that do not exist in the ST e.g., the connotation loaded words unavailable in the ST.

. One example is the translation of the below excerpt from Aesop's fable "The Truth and the Traveller" translated using foregniztion and domestication strategies successively, where the translator of the 
domesticated version well manifest the concept of gain and loss by adding new elements that elevate the connotations implied.

She answered, "Because in former times, falsehood was with few, but is now with all men." (Aesop's fable "The Truth and the Traveller")

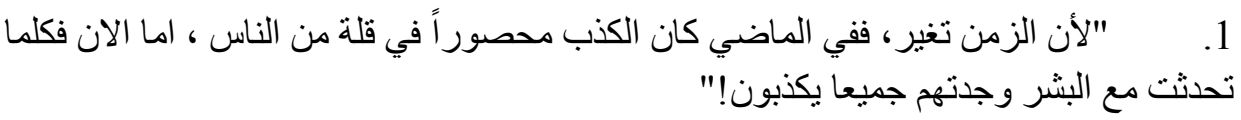

Literally : Time has changed, for in the past, lying was conclusive to few people. Now whenever you talk to people, you find them all lie.

Transliteration: li'ana alzaman tagheiar fafi 'almadhi kãn 'alkathibu mahsuran fi qilatin min alnãs, ama 'alãn fakulama tahdathta ma ${ }^{6}$ albashar wjadatahum jami ${ }^{6}$ an yakthibũn.

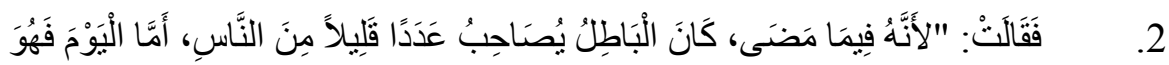

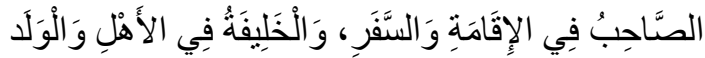

Literally: She said "for in bygone time, falshood accompanied a few number of people. But today it is the companion in travel and settelment and the resident within family and clan".

Transliteration: Faqalat "li' anahu fima madha kãn albãţulu uşãhubu ${ }^{6}$ adadan qalilan min alnãs 'ama alywm fahua alşahibu fi 'al'iqamati wa al safar wa alkhalifatu fi 'ahli wa alwalad”.

Among the parameters raised by three prominent models of TQA ( House, 1997, 2001 Nord, 1991,1997, Hervey and Higgins, 1992, 2002), the following can be highlighted :

1. Textual Typology (province) and Tenor: i.e. the linguistic and narrative structure of ST and TT, textual function (e.g. didactic, informative, instructional, persuasive, evocative...etc.).

2. Formal Correspondence: overall textual volume and arrangement, paragraph division punctuation, reproduction of headings, quotation, mottos, logos... etc. 
3. Coherence of Thematic Structure: degree of referential compatibility and thematic symmetry.

4. Cohesion: reference (co-reference, proforms, anaphora, cataphora), substitution, ellipsis, deixis and conjunctions.

5. Text-Pragmatic (Dynamic) Equivalence: degree of proximity of TT to the intended effect of ST (i.e. fulfillment or violation of reader expectations)and the illocutionary function of ST and TT.

6. Lexical Properties (register): jargon, idioms, loanwords, catch phrases, collocations, paraphrases, connotations and emotive aspects of lexical meaning.

7. Grammatical/ Syntactic Equivalence: word order, sentence structure, cleaving, number, gender and person (agreement), modality, tense and aspect. (Al-Qiani, 2000:499)

Those parameters are considered for adopting an adapted model for TQA. A more objective and scientific methods should be adapted, where the translator or the translation evaluator puts in consideration ideology, function, genre, register and the communicative value of individual linguistic items so s/he can move from a macro-analytical focus to a micro-analytical one. Thus, approaches that cover these considerations ( functionalistic, linguistically oriented and post-modernist approaches ) are adopted to reach an adapted model for TQA.

The adapted model is sought to cover all these parameters and has been applied in the process of translation quality assessment to give insight to merits and demerits of the strategies adopted in translating the material in hand. Some examples ${ }^{1}$ of the employment of this model are:

THE NAUGHTY BOY ( from Hans Christian Andersen's Fairy Tales )

Așabi almushãakis

Alwaladu ashaqi

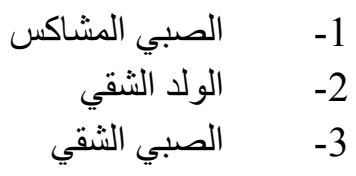

Așabi ashaqi

\footnotetext{
${ }^{1}$ Each translation excerpt is followed by transliteration and a literal translation of the Arabic text.
} 
Translators of the last two texts agree to use " الثشي "ashaqi ) as an equivalent for " naughty " which goes with the modern usage of this word. Yet, in the first text, the translator properly renders it as " المشاكس " (almushãakis) realizing that the word " شقي (shaqi) in standard Arabic refers only to unhappiness or misery (AlRazi, 1986: 343 ) and using it to refer to naughtiness is merely a common mistake.

exclaimed suddenly a child that stood crying at the door and knocking for admittance,

Wa șarakha țiflun fi alkharij .. kãn alțiflu yabki wa yațruqu albã b (And a child shouted outside... the child was crying and knocking the door)

$$
\text { و صرخ طفل في الخارج .. كان الطفل ييكي و يطرق الباب }
$$

șaha hĩnaha yabki wa yaduqu ${ }^{6}$ ala albã b (shouted then, crying and knoking the door)

$$
\text { صاح حينها يبكي و يدق على الباب }
$$

qalaha wa hua yaqra ${ }^{6} u$ albab țaliban aldukhũ l (he said it while he was knocking the door asking for admittance)

$$
\text { قالهاو هو يقرع الباب طالبا الدخول }
$$

The verb " exclaim " implies expressing feelings with a sudden impact (Procter,1984 : 379) . Only the third text literally renders this sense into " فجأة صاح " (faj'a șaḥa “suddenly cried”), while the other two texts endeavour to convey the meaning by introducing the conjunction " و "in the first text and "حينها " ( hinahã " and then") in the second, which both only hint at the time sequence not the exact intended meaning.

The participles " crying " and " knocking " are translated into verbs in all three texts " يبكي و يطرق ، يبكي و يدق ، يقرع " ( yabki wa yaṭuqu , yabki wa yaduqu "cried and knocked"), which leads them to lose the implied sense of the continuity intended. It is suggested that a fully foreignized translation would adequately transfer the desired image:

و تعالت فجأة صيحات طفل على الباب باكياً قار عاً الباب طالباً الدخول 
Wa ta ${ }^{6}$ alat faj'atan saihat tiflin 6ala albab bakian qari6an albab Taliban aldukhul

Suddenly loud shouts were heard of a boy knocking and crying for admittance.

\section{In his hand he held a splendid $\underline{\text { bow, }}$}

Yahmilu fi yadihi qawsan jamĩla ( holding in his hand a nice bow)

$$
\text { 1 }
$$

Kan umsuk fi yadihi qawsan wa nishãban jamĩlain (was holding in his hand a nice bow and an arrow

$$
\text { كان يمسك في يده قوساو نشابا جميلين }
$$

Kan hunãka qawsun latîf fi yadihi ( there was a nice bow in his hand)

$$
\text { كان هناك قوس لطيف في يذه }
$$

The addition of " نشاباً " (nishãban "arrow") in the second text enhances the image of " bow and arrow" whereas, the other two texts which

\begin{tabular}{|c|c|c|}
\hline La az̦inu thãlika & (I don't think so) & لا اظن ذلك \\
\hline Hatha amrun saiy' & ( this is bad) & هذا امر سيء \\
\hline & ( that was sad) & كان هذا محزنا \\
\hline
\end{tabular}
followed the ST and suffice with mentioning only the bow.

\section{"That would be unfortunate,"}

The third text by adopting the literal strategy could not convey the boy's disappointment through using the past tense. The element of surprise ( of the boy's joy in finding out that nothing is wrong with his bow) is also lost in the first text domesticating the disappointment expressed into disagreement "لا اظن ذلك" (La azinu thãlika "I don't think so"). Thus, the nearest adequate translation would be the second text, yet it could also include the element of probability " would " as for example هذا سيكون " 
" امر ا محزنا فعلا (hatha saykũnu amran muhzinan fi ${ }^{6}$ lan "that would be a sad thing indeed").

\section{" $\underline{O h}$, it's quite dry and isn't damaged at all.}

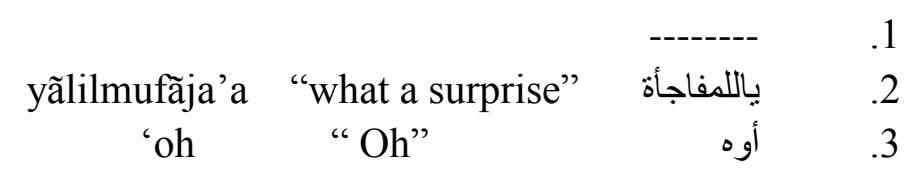

Exclamation markers ( such as the interjection " oh " that indicates surprise in this example ) play an important role as cohesive devices that tie the texts together. This may be manifested by the loss of the effect in the first text due to the translator's omission of this marker. The second text explicates the meaning by rendering it as " ياللمفاجأة (yãlilmufãja'a "what a surprise") while, the third text prefers the alternative of the literal translation " اوه "("oh "oh"). Discourse markers as the case of the exclamation marker above, are dispensable for they are a useful means of telling the reader the kind of relationship the writer intends between two parts of the text ( Halliday and Hasan, 1976: 226) .

So, drawing it back, he took an arrow, aimed, and shot the good old poet right in the heart.

$$
\text { 1. م سحب القوس و وضع السهم و صوب و اطلق على الثناعر الرقيق في قلبه }
$$

thuma sahaba alqaws wa wada ${ }^{6}$ a alsahama wa șawaba wa ațlaqa ${ }^{6}$ ala alsha $a^{6} \mathrm{ir}$ alraqĩq fi qalbih

$$
\text { 2. ثم شد الوتر و سدد النشاب و رمى به الثـاعر العجوز في قلبه }
$$

(the he drew the bow and put the arrow and aimed and shot the delicate poet in his heart)

thuma shada alwatar wa sadada alnishãb wa rama bihi alsha ${ }^{6}$ ir al ${ }^{6}$ ajuz fi qalbih (then pulled the string and aimed the arrow and shot the old poet in the heart)

$$
\text { ثم ثنى رأسه و صوب ..و اطلق سهما على الثاعر العجوز في قلبه }
$$


thuma thana ra'sahu wa sawaba .. wa atlaqa shaman 6ala alsha6ir al6ajuz fi qalbih

(then bowed his head and aimed .. and shot an arrow at the old poet in the heart)

" سحب القوس و وضع السهر " The couplets used by the first two translations (sahaba alqaws wa waḍa ${ }^{6}$ a "asaham "drew the bow and put the arrow") in the first text and " ( alnishãb "pulled the string and aimed the arrow")in the second text are undoubtedly adaptations of the participle " drawing " and the following clause " he took ...." Though the second text manifests a more eloquent

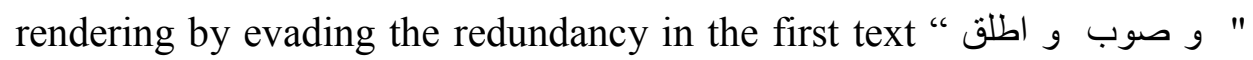
. waḍa ${ }^{6}$ a 'asaham .. wa șawba wa aṭlaqa "put the arrow .... " سدد Aimed and shoot") by using a single verb that is entirely sufficient " (a) ( employing similar sounds " " ش ، س ، ت ، ب " (sh, s, t, b). This usage of phonetic tools ( alliteration ) helps to enhance "The relations of meaning foregrounded in ....relationships of similarity or of contrast; they are reinforced, here and there, by alliteration and assonance " ( Leech \& Short, $1981:$ 113).

\section{but he deceives them all the same, for he is very deep.}

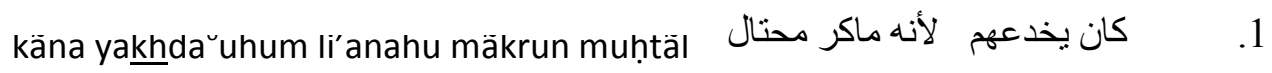
( he was deceiving them for he is cunning and shrewed)

Lakinahu khada ${ }^{6}$ ahum li' anahu muhtãal لكنه خدعهم لانه محتال (but he tricked them for he is cunning)

Lakinahu sakhira minhum li'anahu kãn mãkiran لكنه سخر منهم لانه كان ماكر ا .3 (but he made fun of them because he was shrewed) 
The contradiction of the phrase " all the same " is not rendered in all three texts though, it could be easily stated as " ملى الرغم or " مع ذللك ") " "(ma ${ }^{6}$ a dhãlika , "ala alrughim min hãanlika "despite that"). Also, all the texts miss the modification of " deep " which means " seriously bad or damaging and also mysterious and obscure" (Procter,1990 : 287), and its connotation of human nature ( The beauty is only skin deep ) or the devil in Arabic tradition ( ان الثيطان يجري من الانسان مجرى الدم ) ('ina alshaitãn yajri mina alinsãn majra aladam "the devil runs in man like the blood in the veins"). A suggested rendering is to reveal this connotation by " شيطاني الدهاء " (shaytãniu aldahã" “ devilish cunning”) for example.

\section{At last she bowed her head over a heap of stones}

$$
\text { ، فجعلته بذلك يطأطيء برأسه نحو كومة من الصخور }
$$

Faja ${ }^{6}$ alatuhu bidhalika utạa'ti'u bira'sihi naḥwa kawmatin min asukhũr (thus, made him bow his head towards a heap of rocks)

$$
\text { 2. الوردة تدلت بغصنها على بضع صخور كبيرة }
$$

Alwardatu tadalat bighusnihã ${ }^{6}$ ala biḍ ${ }^{6} i$ șukhũrin kabĩratun

(the rose leaned with its stem over few big rocks)

The first translator shifts the pronoun attribute from the rose" feminine she" to the masculine " nightingale - جعلته " in an endeavour to pursue the precedent image of the tormented lover, while the second text maintains the original image of the rose preparing itself to throw a speech as indicated by the introductory expression "At last ". Nonetheless, the rendering of " heap " into " بضع " (bid "several”) which denotes quantity and the replacing of " her head "with " her stem - غصنها " (ghuṣnuha ) seem deviating from the image intended since "bowing the head" is a show of respect for the dead and "كوم " ( kawmin "heap")

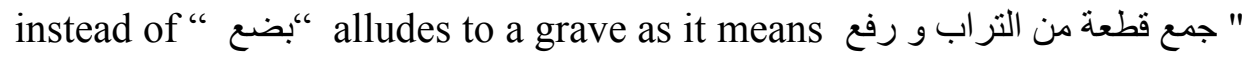
" رأسها ( Al-Rãzi,1986:583 ). 


\section{The field study}

The second major part of the study is to conduct a field study that measures the preference and the acceptance of the chosen material within their designated readers (children according to their age group and reading preferences).

\section{Subjects and material}

Children share the same patterns of reading preferences with adults, as stated by Bamberger (in Klingberg ,2008: 88). These preferences can be concluded as :

- Fantasy and adventure ( romantic preference )

- Factual ( realist preference )

- Knowledge (intellectual preference )

- Literary ( aesthetic preference )

Yet, Bamberger and many other scholars [ (Hunt,2005: 20 ), (Oittinen,2000:41-47), Al-Hitti (1986: 169-190) and Abu Nasr ( in Klingberg 2008: ) ] try to associate these patterns of preferences ( in their quest for reaching an appropriate definition for children's literature ) with age and with what the child considers as "amusing" and "funny".

Arab scholars specialized in the field such as Shahata (1994) and Abu Maal (1988) investigate the Arab children's reading preferences and readability to define what Arab children read and what are the kinds of literature that intricate them. Those can be clearly conceived as stages following Al-Hitti (1986: 18), Shahata ( 1994: 118-142) and Abu Maal (1988: 22-25) who identify development of children's readability in the following four stages ( though not fixated but dearly intermixed ).

1. Limited imagination stage : includes children from 3-5 years old.

2. Blooming imagination stage : includes children from 6-8 years old.

3. Heroism stage : includes children from 8-12 years old.

4. Idealism stage : includes children from 12-15 years old. 
The present study is based on literature oriented toward the third and fourth sections of the divisions above as the first and second sections are regarded as preliminary stages for learning and fumbling through language and new lexics and early endeavours for understanding ( $\mathrm{Abu}$ maal, 1988: 22).

Thus, the age of the subjects is determined to be from 8-15 years old divided into two groups; the first group includes primary schools students (10-11 years old) and the second group comprises intermediate school students ( $12-15$ years old). Sex is taken into consideration, so the specimens include both male and female subjects.

The first group subjects are introduced to fables as a material for the study since this group age limit is identified with imagery and moral oriented reading preferences (Abu maal, 1988 :23 and Al-Hitti 1986: 19,30).

The second group subjects are introduced to fantasy and morally intense social stories ( Hans Christian Andersen's) since the age limit in this group is identified with not only imagery but also social and religious reading orientation as well ( ibid).

\section{Aesop's Fables :}

$$
\text { ترجمة قصص ابيوب الخر/فية ترجمة احمد الليثي }
$$

Tarjamat Qisas Isop AlKhurafya ( Translation of Aesop's Fables ) translated by AlLaythy, A.

حكايات ابيوب ، ترجمة و تعليق - امام عبد الفتاح امام

Hikayãt Isop: Dirãsa wa Ta6lyqwa Tarjama (Aesop's Fables: A Study,

Commentary and Translation) translated by Imam, A. I.

القصص الحكيم للفيلسوف /ببوب ، ترجمة مصطفى السقاو سعيل جودة السحار

AlQaşaş AlHakym LilFailasũf Isop ( The Wise Stories of Aesop, The

Philosopher) translated by AlSaqa, M. and AlSahar S. J. 


\section{Fairy Tales}

حكايات هانز كريبتيان اندرسن ترجمة كاظم سعد الدين

Hikayat Hanz Kistian Andersin (Hans Christian Andersen's FairyTales) translated by SaduDin, K.

حكايات اندرسن ترجمة عبد الحميد يونس

Hikayat Andersin (Andersen's FairyTales) translated by Younis, A.

حكايات اندرسن ترجمة احمد خالد توفيق

Hikayat Andersin (Andersen's FairyTales) translated by Tawfĩq, A $\underline{\text { Kh}}$.

\section{Findings}

The study field results have been subjected to verification process via conducting a chi-square test to validate the results regarding four major criteria sought in the field study namely, the level of difficulty of the texts, the subjects' preferences of the texts, the subjects' recognition of the antiquity of the texts and their preferences of the story types.

The results are statistically validated since all chi-square values $\left(\mathrm{X}^{2}\right)$ are less than the alpha values ( $p$ ) as shown in table (3) below:

\begin{tabular}{|c|c|c|c|c|c|c|}
\hline \multicolumn{3}{|c|}{ Chi-Square Tests } & Value & Df & Asymp. Sig & Alpha value \\
\hline \multirow{8}{*}{$\begin{array}{c}\text { GROUP } \\
\text { ONE }\end{array}$} & DIFFICULTY & Pearson Chi-Square & $12.000^{\mathrm{a}}$ & 9 & .213 & 16.92 \\
\hline & $\mathrm{X}^{2}(9)=12, p \leq 16.9$ & & & & & \\
\hline & PREFERENCE & Pearson Chi-Square & $6.000^{\mathrm{a}}$ & 4 & 199 & 9.49 \\
\hline & $\mathrm{X}^{2}(4)=6, p \leq 9.49$ & & & & & \\
\hline & NOVELTY & Pearson Chi-Square & $6.000^{\mathrm{a}}$ & 4 & .199 & 9.49 \\
\hline & $\mathrm{X}^{2}(4)=6, p \leq 9.49$ & & & & & \\
\hline & STORY TYPE & Pearson Chi-Square & $35.000^{\mathrm{a}}$ & 30 & .243 & 43.77 \\
\hline & $\mathrm{X}^{2}(30)=35, p \leq 43$. & & & & & \\
\hline
\end{tabular}




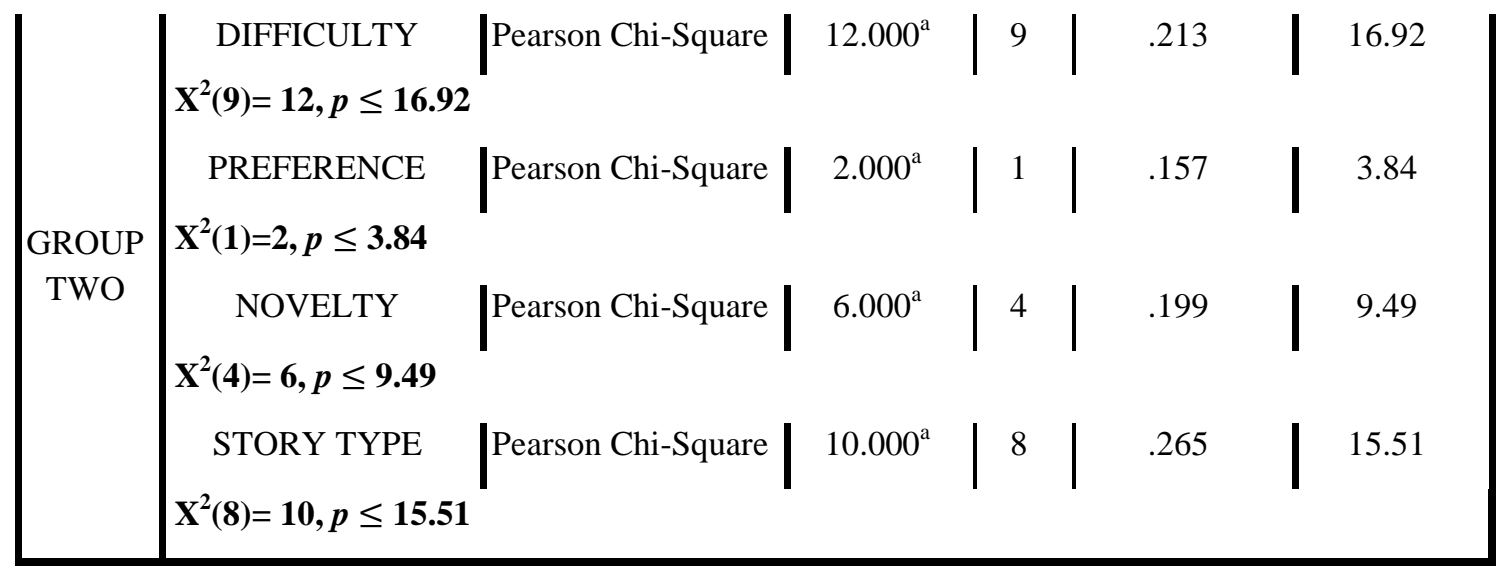

\section{Table (3) Chi-Square Tests}

The theoretical discussion backed up by the statistical results revealed the following :

Only the third thesis is fully verified. The first thesis is not validated for it has been proved that strategies in translating this kind of literature are applicable and enjoyable only if the age group is taken into consideration, and hence comes the importance of the translation brief as an effective aid for the translator to be acquainted with the type of readers and their interest. Accordingly, the first thesis is only valid if applied to a certain age group which in this case comprises children ranging from 8 to 12 years old ( the age of Heroism stage of reading preferences), while the older age group ( children from 12 to 15 years old who belong to Idealism stage of reading preferences) seems to enjoy a different strategy adopted translation. This leads to the annulling of the second thesis and restricting its assumption to the age group of the Idealism stage.

The findings of this study can be viewed in the light of children's reading preferences and the translation strategies adopted differ from one group to another. The children who belong to the Heroism stage ( 8-12) enjoy translations adopting the domestication strategy for they are closer to their intellectual comprehension and their needs, while the older age 
group ( of Idealism stage) seeks a more sophisticated attending in addressing their evolved curiousity and desire for exploring the exotic and unfamiliar. And to fulfill these needs, the translator should adopt a strategy that manifests the exotic and alien elements in the text in hand by adopting the foreignization strategy.

This, by no means, indicates that the translator should only stick to a single strategy within the whole text since even when adopting the domestication strategy, s/he can resort to foreignization or literal strategy in some points for various reasons such as for didactic purposes.

\section{Conclusions}

1. The first thesis proves to be not entirely applicable since it indicates a generalized aspect of using domestication translation strategy, since it has been found that the age group defines the translation strategy to be adopted.

2. Setting out from the previous point, translation strategies of children's literature should be based on the age groups and orientation of children's reading preferences.

3. Since the study deals with primarily two age groups; namely, heroism stage and idealism stage, domestication strategy proves to be the most appropriate option to be adopted in translating for children belonging to heroism stage ( 8-12 years old) since it draws the child's attention and interest in the material in hand. On the other hand, foreignization strategy seems to be more attractive for the older age group of children that belongs to the idealism stage (12-15 years old), because it opens wide new horizons of knowledge and new information which answers the needs of this age group. This, in its turn, proves the invalidity of the second thesis in its general sense.

4. However, this result does not dictate adherence to a one single strategy in the whole process of translation. For example in a domesticated translation, the translator can manifest the exotic elements of the text using annotation, explanation, ellipsis or even 
literal translation. The same also goes for texts translated adopting the foreignization strategy.

5. "Translation brief" should be an integral part of the translation process since it equips the translator with the necessary information about the genre, the age group of intended readers and the aimed functional purposes whether entertaining or didactic.

\section{References}

Abu Maal, A. (1988). Adab Alatfãl: Dirãsa waa Tațbyq. (The literature of Children: A Study and Application ). Amman: AlShorũq Int. publication.

Aesop's Fables. (n.d). Retrieved October 20, 2012, from http://www.planetpdf.com/.

Al-Qiani, J. (2000). Translation Quality Assessment. Strategies, Parameters and Procedures. Meta: Translator's Journal, XLV, 3, 497519.

AlHiti, H. N. (1986). Adab AlAtfãl: Falsafatahu, Finũnahu, Wașã'ițahu (Children's Literature: Its Philosophy, Artistic Tools and Methods ). Cairo: State Establishment of Publishing.

AlLaythy, A. ( n.d). Tarjamat Qisas Isop AlKhurafya ( Translation of Aesop's Fables ). International Association for Arabic Translators. Retrieved December 10, 2012, from http://www.atinternational.org/.

AlSaqa, M. \& AlSahar, S. (1977). AlQaşaș AlHakym LilFailasũf Isop ( The Wise Stories of Aesop, The Philosopher). Cairo: Egypy Publishing House.

Andersen, H. C. (2010). Andersen's Fairy Tales. (J. H. Stickney, Ed.) Project Gutenberg's Hans Andersen's Fairy Tales. Retrieved October 20, 2012, from http://www.gutenberg.org/

Catford, J. C. (1965). A Linguistic Theory of Translation. Oxford: Oxford University Press.

Dickins, J, Hervey. S. \& Higgins, I. (2002): Thinking Arabic Translation. A Course in Translation. London: Routledge. 
Even-Zohar, I. (2000). The Position of Translated Literature within The Literary Polysystem. In L. Venuti, The Translatoion Studies Reader (192-197). London: Routledge.

Gentzler, E. (1993). Contemporary Translation Theories. London: Routledge.

Hans Christian Andersen's Fairy Tales. (n.d.). Retrieved April 22, 2013, from Hans Christian Andersen's Fairy Tales. http://www.blackmask.com

Hervey, S. \& Higgins, I. (1992): Thinking Translation. A Course in Translation Method: French to English. London: Routledge

House, J. (1977). A model for translation quality assessment. Meta, 22: 103-109.

House, J. (2001). Translation quality assessment: linguistic description versus social evaluation. Meta, 46: 243-257

Hunt, p. (Ed.). (2005). International Companion Encyclopedia of Children's Literature. London: Routledge.

Imam, A. I. (2003). Hikayãt Isop: Dirãsa wa Ta ${ }^{6}$ lyqwa Tarjama ( Aesop's Fables: A Study, Commentary and Translation ). Baghdad: AlMada House.

Klingberg, G. (2008). Facets of Children's Literature Research. (Ed.) Stockholm: The Swedish Institute for Childrren's Books.

Munday, J. (2001). Introducing Transaltion Studies: Theroies and Applications. London and New York: Routledge.

Nida, E. (1964). Toward a Science of Translating. Leiden: Brill.

Nord, C (1991). "Scopos, Loyalty and Translational Conventions." Target, 3,1: 91-109

Nord, C. ( 1997 ). A Translation-Oriented Model of Text Functions. TEFLIN

Journal, 17, 2: 39-45.

Nord, C. (2006): Translating as a Purposeful Activity. Functionalist Approaches Explained. Manchester: St. Jerome 
Oittinen, R. (2000). Translating for Children. New York and London: Garland.

Shihaata, H. (1994). Adab AlȚifil Al ${ }^{6}$ arabi: Dirasãt wa Buhũth (Arab Children's Literature: Studies and Researches). Cairo: Egyptian Lebanese House.

Shavit, Z. (1986). Poetics of Children's Literature. Athens and London: The University Of Georgia Press.

Tabbert, R. (2002). Approaches to the translation of children's literature. A review of critical studies since 1960. Target, 14(2), 303351.

Tawfyq, A. Kh. (1988). Hikayãt Andersin (Andersen's FairyTales ). Cairo: AlHilãl House for Publishing and Printing.

Venuti, L. (1995). The Translator's Invisibility: A History of Translation. New York: Routledge.

Venuti, L. (2000). Strategies of Translation. In M. Baker (Ed.), Routledge Encyclopedia of Translation Studies. London and New York: Routledge.

Younis, A. (1986). Hikayat Andersin (Andersen's FairyTales ). Baghdad: AlMada House.

\section{About the authors}

Supervisor Asst. Professor Baydaa A. Lateef (Ph.D.). A teaching staff member in Department of Translation. Specialized in machine translation. Translated three books from English into Arabic and published a large number of translated essays and papers in Iraq and Arab journals. Taught in Arab universities and supervised M.A translation students. Worked in a research institution on machine translation. Interested in translation and technology.

Email: dr.baydaa99@uomustansiriyah.edu.iq 
Ala‘a Jasim Obaid MA. Candidate B.A.\&M.A. in Translation/ College of Arts/ Almustansiriah University. Assistant manager at the Iraqi Council for Medical Specializations of the Medical Journal website. Designer of the Scientific Council of Cardiology website.

Email: ajalkinany@gmail.com

$$
\begin{aligned}
& \text { بين التقريب و التغريب : } \\
& \text { مدخل الى ترجمة قصص الاساطير و القصص الخرافية } \\
& \text { طالب الاراسات علاء جاسم عبيد } \\
& \text { الجامعة المستنصرية ـ كلية الاداب ـ قسم الترجمة } \\
& \text { ا.م.د. بيذاء علي العبيدي الابي } \\
& \text { الجامعة المستنصرية ـ كلية الاداب ـ قسم الترجمة }
\end{aligned}
$$

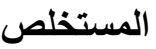

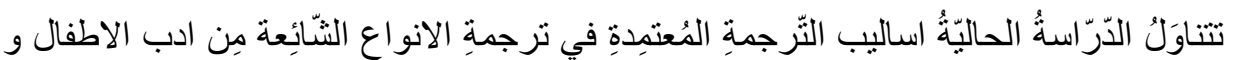

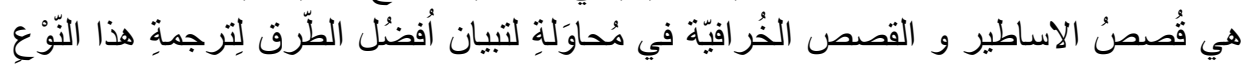

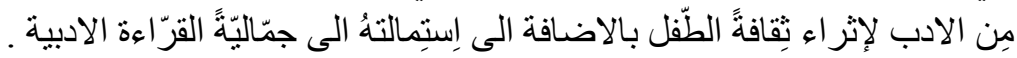

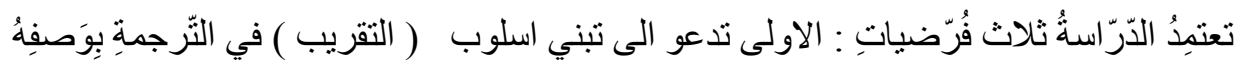

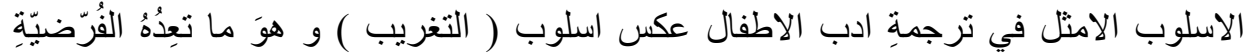

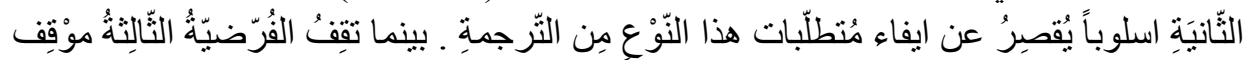

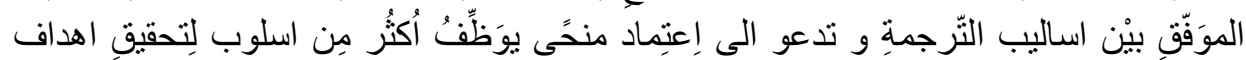

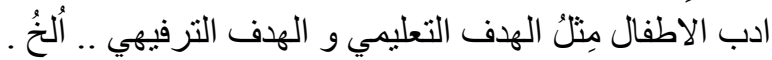

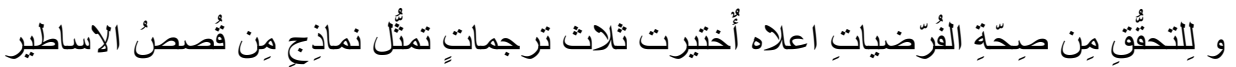

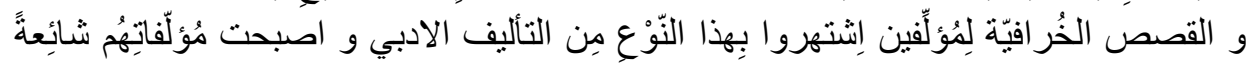

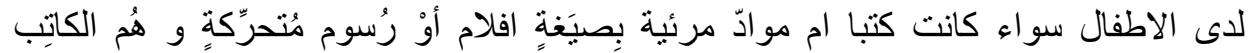

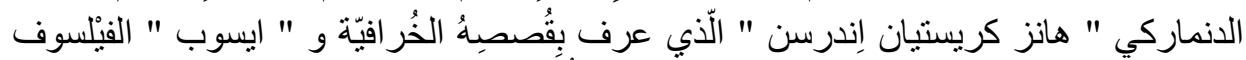

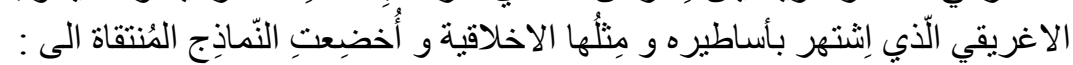

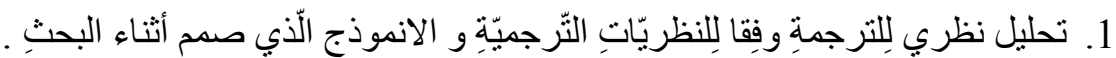

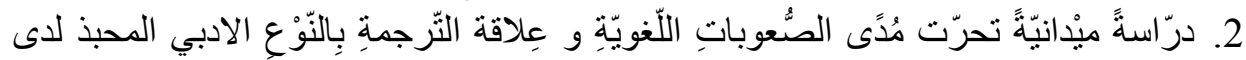

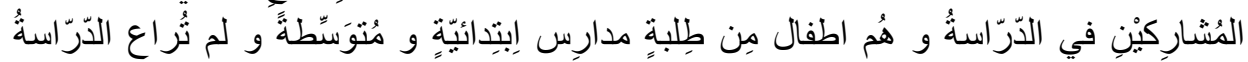

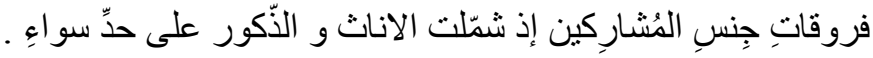
الكلمات المفتاحية: ادب الاطفال، التقريب، القصص الخر افية. 